\author{
Maciej Rogalski \\ Uczelnia Łazarskiego, Polska \\ ORCID: 0000-0003-4366-642X \\ maciej@rogalski.waw.pl
}

\title{
Glosa do wyroku Wojewódzkiego Sądu Administracyjnego w Warszawie z dnia 25 czerwca 2019 r. (VI SA/Wa 904/19)'
}

\author{
Gloss to the Judgement of the Voivodeship Administrative Court in \\ Warsaw of 25 June 2019 (VI SA/Wa 904/19)
}

\section{STRESZCZENIE}

Postanowienia art. 99 ust. 4 ustawy Prawo farmaceutyczne przewidują wymagania dla uzyskania pozwolenia na prowadzenie apteki ogólnodostępnej przez dany podmiot. Podmiot prowadzący aptekę uzyskał zezwolenie przed zmianą tego przepisu przez nowelę Prawa farmaceutycznego, ale wystąpił o jego zmianę po wejściu w życie tej noweli. Zarówno Wojewódzki Inspektor Farmaceutyczny, jak i Główny Inspektor Farmaceutyczny uznali, że podmiot występując o zmianę zezwolenia na prowadzenie apteki, które to zezwolenie uzyskał przed wejściem w życie ustawy nowelizującej, musi spełniać wymogi nałożone obecnie obowiązującymi przepisami Prawa farmaceutycznego. Wojewódzki Sąd Administracyjny w Warszawie uchylił zaskarżone przez podmiot wnioskujący o zmianę zezwolenia decyzje obu instancji. Glosa do wyroku Sądu jest krytyczna, w szczególności w zakresie interpretacji przez Sąd przepisów intertemporalnych zawartych w ustawie nowelizującej.

Słowa kluczowe: prowadzenie apteki; zezwolenie na prowadzenie apteki; zmiana zezwolenia na prowadzenie apteki; odmowa zmiany zezwolenia

Wojewódzki Sąd Administracyjny w Warszawie po rozpoznaniu na rozprawie w dniu 25 czerwca 2019 r. sprawy ze skargi E. Sp. z o.o. Sp. j. z siedzibą w O. na decyzję Głównego Inspektora Farmaceutycznego z dnia [...] marca 2019 r. nr [...] w przedmiocie odmowy zmiany zezwolenia na prowadzenie apteki uchylił zaskarżoną decyzję i poprzedzającą ją decyzję [...] Wojewódzkiego Inspektora Far-

\footnotetext{
1 Legalis nr 2215467, CBOSA.
} 
maceutycznego z dnia [...] listopada 2018 r. oraz zasądził od Głównego Inspektora Farmaceutycznego na rzecz skarżącej E. Sp. z o.o. Sp. j. z siedzibą w O. kwotę 697 (sześćset dziewięćdziesiąt siedem) złotych tytułem zwrotu kosztów postępowania.

W uzasadnieniu do tego wyroku Wojewódzki Sąd Administracyjny w Warszawie wskazał, że decyzją z dnia [...] marca 2003 r. znak: [...], [...] Wojewódzki Inspektor Farmaceutyczny w Warszawie udzielił E. Sp. z o.o. z siedzibą w M. (dalej „skarżąca”, „strona” lub „spółka”) zezwolenia (koncesji) (dalej: „zezwolenie”) na prowadzenie apteki ogólnodostępnej w P. przy ul. S. nr [...] (dalej: „apteka”). Przedmiotowe zezwolenie zostało następnie zmienione innymi decyzjami.

Na wniosek skarżącej z dnia 17 października 2018 r. zostało wszczęte postępowanie $\mathrm{w}$ sprawie dokonania zmiany ww. zezwolenia na prowadzenie apteki w zakresie nazwy oraz adresu podmiotu prowadzącego aptekę z E. [...] K. Sp. j. z siedzibą w J. na E. W. Spółka z ograniczoną odpowiedzialnością spółka jawna z siedzibą w O. ul. B.

Złożenie powyższego wniosku uzasadnione było dokonanymi przekształceniami w Spółce. Spółka, składając wniosek, uzasadniała konieczność zmiany w składzie osobowym wnioskującej spółki poprzez rozszerzenie jej składu osobowego o nowo utworzoną spółkę W. sp. z o.o. Pismem z dnia 31 października 2018 r., [...] Wojewódzki Inspektor Farmaceutyczny w W. (dalej: „WIF”) poinformował Stronę o zamiarze zakończenia postępowania i wydania decyzji. Jednocześnie organ pouczył o treści art. 99 ust. 4 pkt 2 ustawy prawo farmaceutyczne (Dz.U. 2001 Nr 126 poz. 1381 dalej ,u.p.f.”) i wynikającym z niego braku możliwości rozszerzenia osobowego składu spółki jawnej o wspólnika będącego spółką kapitałową.

W odpowiedzi na zawiadomienie strona wskazała, że ustawa $\mathrm{z}$ dnia 7 kwietnia 2017 r. o zmianie ustawy - prawo farmaceutyczne (Dz.U. z 2017 r., poz. 1015 dalej ,ustawa nowelizująca”), która wprowadziła art. 99 ust. 4 pkt 2, w art. 2 ust. 2 stanowi, iż zezwolenia na prowadzenie aptek ogólnodostępnych wydane przed dniem wejścia w życie ustawy zachowują ważność. Ponadto skarżąca wskazała, iż - zarówno przed zmianą składu osobowego wspólników i siedziby ww. Spółki Jawnej, jak i po dokonanej zmianie skład osobowy wspólników obejmował i obejmuje osoby niebędące farmaceutami posiadającymi prawo wykonywania zawodu, obok wspólnika posiadającego prawo do wykonywania zawodu.

Decyzją z dnia [...] listopada 2018 r., znak: [...], WIF odmówił dokonania zmiany zezwolenia. Organ pierwszej instancji w powołanym rozstrzygnięciu wskazał, że wnioskowana zmiana dotyczyła faktycznie zmiany kręgu wspólników spółki jawnej, nie zaś samej firmy Spółki oraz jej siedziby. Zawnioskowane zmiany nie mogą być w ocenie organu I instancji dokonane $\mathrm{z}$ uwagi na obecne brzmienie przepisów Prawa farmaceutycznego.

Strona, pismem z dnia 27 listopada 2018 r., za pośrednictwem WIF, wniosła do Głównego Inspektora Farmaceutycznego (dalej: „GIF” lub „organ II instancji”) odwołanie od powyższej decyzji organu I instancji, zaskarżając ją w całości 
i zarzucając naruszenie przepisów ustawy „Prawo farmaceutyczne”, ustawy nowelizującej, oraz ustawy z dnia 6 marca 2018 r. Prawo przedsiębiorców (Dz.U. poz. 646 ze zm., dalej: „u.p.p.”).

Decyzją z dnia [...] marca 2019 r. GIF utrzymał w mocy zaskarżoną decyzję organu I instancji. W uzasadnieniu wskazał, że organ I instancji prawidłowo uznał, że podmiot, występując o zmianę zezwolenia na prowadzenie apteki, które to zezwolenie uzyskał przed wyjściem w życie ustawy nowelizującej, musi spełniać wymogi nałożone obecnie obowiązującymi przepisami Prawa farmaceutycznego. Ponadto wskazał na przepis art. 2 ustawy nowelizującej, który zawiera normę intertemporalną (międzyczasową). Zdaniem organu celem ustawodawcy było, aby poza sytuacjami wyraźnie uregulowanymi przepisem intertemporalnym, od dnia 25 czerwca 2017 r. stosowane były przepisy ustawy - Prawo farmaceutyczne w brzmieniu nadanym ustawą nowelizującą, która zmieniła także treść art. 99 ust. 4 u.p.f. Organ II instancji podzielił stanowisko organu I instancji, że zmianie zezwolenia w części dotyczącej zmiany nazwy podmiotu uprawnionego do prowadzenia apteki sprzeciwia się art. 99 ust. 4 pkt 2 u.p.f., który stanowi, że prawo do uzyskania zezwolenia na prowadzenie apteki ogólnodostępnej posiada spółka jawna lub spółka partnerska, której przedmiotem działalności jest wyłącznie prowadzenie aptek i w której wspólnikami (partnerami) są wyłącznie farmaceuci posiadający prawo wykonywania zawodu, o którym mowa w art. $4 \mathrm{i}$ art. 4 b ustawy z dnia 19 kwietnia 1991 r. o izbach aptekarskich. Nowy wspólnik to spółka kapitałowa - W. spółka z ograniczoną odpowiedzialnością z siedzibą w O. Według GIF wspólnik ten nie spełnia wymogu bycia farmaceutą i posiadania prawa wykonywania zawodu farmaceuty.

Skarżąca w dniu 1 kwietnia 2019 r. wniosła skargę na powyższą decyzję oraz wniosła o uchylenie decyzji organów obu instancji. Skarżąca zarzuciła GIF naruszenie: art. 108 ust. 4 pkt 4 lit. a i art. 99 ust. 2 w zw. z art. 37 ar, art. 99 ust. 4 pkt 2 , art. 100 ust. 1 pkt 1, art. 101 pkt 1, art. 102 pkt 1 u.p.f. i art. 2 ust. 2 ustawy nowelizującej oraz w zw. z art. 6, art. 7a, art. $8 \S 1$, art. 11, art. $104 \S 1$ i art. 155 k.p.a. poprzez ich błędną wykładnię oraz niewłaściwe zastosowanie polegające na przyjęciu, że zmiana wspólnika spółki jawnej posiadającej zezwolenie na prowadzenie apteki ogólnodostępnej poprzez uzyskanie statusu wspólnika przez spółkę z ograniczoną odpowiedzialnością po dniu 24 czerwca 2017 r. stanowi przesłankę do odmowy zmiany zezwolenia na prowadzenie apteki ogólnodostępnej w zakresie nazwy i siedziby podmiotu; naruszenie art. 8, art. 11 ust. 1 oraz art. 41 ust. 2 ustawy Prawo przedsiębiorców (dalej „u.p.p.”) poprzez ich niezastosowanie.

Wojewódzki Sąd Administracyjny w Warszawie wyrokiem z dnia 25 czerwca 2019 r. uchylił decyzję Głównego Inspektora Farmaceutycznego z dnia [...] marca 2019 r. $\mathrm{nr}[\ldots]$ w przedmiocie odmowy zmiany zezwolenia na prowadzenie apteki oraz poprzedzającą ją decyzję [...] Wojewódzkiego Inspektora Farmaceutycznego $\mathrm{z}$ dnia [...] listopada $2018 \mathrm{r}$. 
Wojewódzki Sąd Administracyjny w Warszawie, wyjaśniając powody swojego rozstrzygnięcia, trafnie wskazał, że istota sporu sprowadza się do ustalenia, czy do wniosku skarżącej o zmianę zezwolenia na prowadzenie apteki ogólnodostępnej, w zakresie dotyczącym zmiany nazwy i adresu prowadzonej działalności, mają zastosowanie wprowadzone ustawą nowelizującą przepisy zawierające ograniczenia osobowe dla firm prowadzących apteki ogólnodostępne.

Sąd także trafnie zauważył, że przedmiotowa nowelizacja zawiera przepisy intertemporalne określające intencje ustawodawcy odnośnie do obowiązywania w czasie przepisów nowych oraz dotychczasowych. Zgodnie z przepisem art. 2 ustawy nowelizującej, zawierającym normy intertemporalne, „do postępowań wszczętych i niezakończonych przed dniem wejścia w życie ustawy dotyczących wniosków o wydanie zezwolenia na prowadzenie apteki stosuje się przepisy dotychczasowe (ust. 1). Zezwolenia na prowadzenie aptek ogólnodostępnych wydane przed dniem wejścia w życie ustawy zachowują ważność (ust. 2)”. Według Wojewódzkiego Sądu Administracyjnego w Warszawie z treści tych przepisów jednoznacznie wynika, że ustawodawca dokonał podziału wydawanych zezwoleń na prowadzenie aptek ogólnodostępnych na zezwolenia funkcjonujące w obrocie na „starych” oraz na „,nowych” zasadach. Wynika to także z faktu, że nie określił żadnego terminu dostosowania funkcjonujących wcześniej zezwoleń do nowych zasad, co oznacza, że nie ustają skutki prawne działania „starego" prawa. Tym samym w bieżącym obrocie pozostają, na równych prawach, lecz odmiennych zasadach, dwa rodzaje zezwoleń na prowadzenie aptek, w zależności od terminu wystąpienia $\mathrm{z}$ wnioskiem o ich wydanie. Jednocześnie w znowelizowanych przepisach Prawa farmaceutycznego ustawodawca uregulował jedynie zasady uzyskiwania nowych zezwoleń. Brak jest zatem jednoznacznie określonego trybu dokonywania zmiany zezwoleń dotychczas funkcjonujących.

Z przedstawioną przez Wojewódzki Sąd Administracyjny w Warszawie interpretacją postanowień art. 2 ustawy nowelizującej nie można się zgodzić z następujących powodów.

Przepis art. 2 ust. 1 ustawy nowelizującej oznacza, że jeżeli postępowanie administracyjne o udzielenie zezwolenia na prowadzenie apteki ogólnodostępnej zostało wszczęte przed dniem wejścia w życie ustawy nowelizującej, czyli przed dniem 25 czerwca 2017 r., oraz do tego dnia nie zostało jeszcze zakończone, to warunki prowadzenia apteki, w szczególności udzielenia lub odmowy udzielenia zezwolenia, określają postanowienia ustawy Prawo farmaceutyczne w brzmieniu przed zmianami wprowadzonymi ustawą z dnia 7 kwietnia 2017 r. Z kolei wnioskując a contrario, z przepisu art. 2 ust. 1 ustawy z dnia 7 kwietnia 2017 r. wynika, że w sytuacji gdy postępowanie administracyjne w sprawie zezwolenia na prowadzenie apteki ogólnodostępnej zostało wszczęte już po wejściu w życie ustawy nowelizującej, czyli w dniu 25 czerwca 2017 r. lub później, to warunki prowadzenia apteki, w szczególności udzielenia lub odmowy udzielenia zezwolenia, określają postanowienia ustawy Prawo 
farmaceutyczne $\mathrm{w}$ brzmieniu nadanym ustawą nowelizującą. W takim przypadku organ właściwy w sprawie o zezwolenie jest obowiązany zbadać, czy przedsiębiorca występujący z wnioskiem o zezwolenie spełnia warunki wykonywania działalności polegającej na prowadzeniu apteki ogólnodostępnej, które zostały w tym zakresie ustalone w ustawie nowelizującej. W szczególności dotyczy to art. 99 ust. 4 pkt 2 u.p.f. W konsekwencji przedsiębiorcy występującemu z wnioskiem o udzielenie zezwolenia na prowadzenie apteki ogólnodostępnej po wejściu w życie ustawy nowelizującej organ właściwy w sprawie zezwolenia powinien odmówić udzielenia zezwolenia, jeżeli przedsiębiorca ten nie spełnia warunków wykonywania omawianej działalności przewidzianych w ustawie Prawo farmaceutyczne w brzmieniu ustalonym ustawą nowelizującą. Taka sytuacja miała miejsce $\mathrm{w}$ rozpatrywanej sprawie. $\mathrm{Z}$ wnioskiem o zmianę zezwolenia wystąpił podmiot po wejściu w życie ustawy nowelizującej, tj. w dniu 17 października $2018 \mathrm{r}$.

Przedstawiona interpretacja nie tylko jest zgodna z podstawowymi zasadami wykładni postanowień art. 2 ustawy nowelizującej, lecz także znajduje oparcie $\mathrm{w}$ powszechnie akceptowanych $\mathrm{w}$ doktrynie ${ }^{2}$ oraz $\mathrm{w}$ orzecznictwie sądowym regułach intertemporalnych prawa administracyjnego. W szczególności, zgodnie z regułą tempus regit factum, organ administracji orzeka co do zasady na podstawie stanu prawnego (i faktycznego) obowiązującego w dniu orzekania, chyba że co innego wynika $\mathrm{z}$ wyraźnego brzmienia ustawowego przepisu intertemporalnego. Reguła tempus regit factum oznacza również przyjęcie dalszego działania dawnego prawa w stosunku do grupy stanów faktycznych jako „naznaczonych” oceną normatywną dawnego prawa ${ }^{3}$. Należy podkreślić, że w przypadku norm prawa administracyjnego konkretyzowanych władczo przez organy administracji w poszczególnych stanach faktycznych, wskazanym „naznaczeniem” stanu faktycznego przez dawne prawo jest fakt wszczęcia postępowania administracyjnego na wniosek zainteresowanego podmiotu pod rządami dawnego prawa. W takim przypadku do danego postępowania administracyjnego, wszczętego pod rządami dawnego prawa, powinno mieć zastosowanie dawne prawo. Natomiast w sytuacji, gdy nie zostało wszczęte postępowanie pod rządami dawnego prawa albo zostało wszczęte, ale już zostało zakończone, stosuje się nowe przepisy.

2 Zob. T. Kiełkowski, Sprawa administracyjna, Kraków 2004, s. 59-61; J. Zimmermann, Problem ,, beneficium novorum” w postępowaniu administracyjnym, „Państwo i Prawo” 1987, z. 5, s. 64; M. Kamiński, Prawo administracyjne intertemporalne, Warszawa 2011, s. 563 i n.; A. Błaś, J. Boć, Przepisy przejściowe w prawie administracyjnym, [w:] Prawo administracyjne, red. J. Boć, Wrocław 2005, s. 115 i n.; J. Zimmermann, Prawo administracyjne, Warszawa 2014, s. 54 i n.; J. Mikołajewicz, Prawo intertemporalne. Zagadnienia teoretycznoprawne, Poznań 2000, s. 62 i n.

3 Zob. wyrok NSA z dnia 6 sierpnia 2013 r., I FSK 1274/12, Legalis nr 737870; wyrok NSA z dnia 1 sierpnia 2013 r., I FSK 1245/12, Legalis nr 737538, pkt 5.11 uzasadnienia; wyrok NSA z dnia 22 maja 2015 r., I OSK 2454/13, www.orzeczenia-nsa.pl; uchwała NSA z dnia 19 października 2015 r., II OPS 1/15, www.orzeczenia-nsa.pl. 
$\mathrm{W}$ orzecznictwie sądowym prezentowane jest analogiczne stanowisko 4 . W wyroku z dnia 7 maja 2002 r. ${ }^{5}$ Sąd Najwyższy - Izba Administracyjna, Pracy i Ubezpieczeń Społecznych wyjaśnił, że „zmiana przepisów prawa materialnego w toku postępowania administracyjnego, między wydaniem decyzji w pierwszej instancji a rozpatrzeniem odwołania, zobowiązuje organ odwoławczy do uwzględnienia nowego stanu prawnego, jeżeli z nowych przepisów nie wynika inny skutek". Wyrok ten jest zgodny $\mathrm{z}$ utrwalonym w orzecznictwie sądowym poglądem, według którego organ odwoławczy jest obowiązany uwzględniać zmiany stanu prawnego i faktycznego, jakie zaszły w sprawie po wydaniu zaskarżonej decyzji organu pierwszej instancji ${ }^{6}$. Kompetencje orzecznicze organu odwoławczego nie sprowadzają się zatem jedynie do kontroli zasadności zarzutów podniesionych w stosunku do decyzji organu pierwszej instancji. Zgodnie z poglądem wyrażonym przez Naczelny Sąd Administracyjny w Warszawie w wyroku z dnia 21 grudnia 1999 r. ${ }^{7}$ organ administracyjny pierwszej instancji stosuje przepisy prawa materialnego obowiązujące w dniu wydania przezeń decyzji. Organ odwoławczy powinien z kolei ocenić sprawę według przepisów prawa materialnego obowiązujących w dniu wydania przez ten organ decyzji odwoławczej. Oznacza to, że jeśli przepisy prawa materialnego ulegną zmianie w czasie między wydaniem decyzji w pierwszej instancji a rozpatrzeniem odwołania, organ odwoławczy - zachowując tożsamość sprawy - obowiązany jest uwzględnić nowy stan prawny, chyba że z nowych przepisów wynika coś innego. Organ odwoławczy orzeka bowiem w sposób merytoryczny (apelacyjny).

Do analizowanego stanu faktycznego nawiązuje wyrok Wojewódzkiego Sądu Administracyjnego w Warszawie z dnia 23 sierpnia 2018 r. ${ }^{8}$ Sąd w uzasadnieniu tego wyroku wyjaśnił, że „w dniu złożenia przez Spółkę wniosku o udzielenie zezwolenia na prowadzenie apteki ogólnodostępnej [...], obowiązywały przepisy u.p.f. przewidujące, iż prawo do uzyskania zezwolenia na prowadzenie apteki ogólnodostępnej posiadała osoba fizyczna, osoba prawna oraz niemająca osobowości prawnej spółka prawa handlowego. Jednakże w dniu 25 czerwca 2017 r. w związku z wejściem w życie ustawy z dnia 7 kwietnia 2017 r. o zmianie ustawy Prawo farmaceutyczne - prawo do uzyskania przedmiotowego zezwolenia, w myśl nowego brzmienia art. 99 ust. 4 u.p.f., utraciły podmioty prowadzące działalność w formie spółki kapitałowej, w tym m.in. spółki z ograniczoną odpowiedzialnością. [...] W związku z faktem, iż wniosek Skarżącej został doręczony organowi I in-

4 Zob. wyrok WSA w Warszawie z dnia 27 lipca 2017 r., II SA/Wa 305/17, Legalis nr 1681565; wyrok WSA w Krakowie z dnia 12 września 2018 r., II SA/Kr 598/18, Legalis nr 1825871.

5 III RN 59/01, OSNAPiUS 2003, nr 3, poz. 56, Legalis nr 55730.

6 Por. wyrok NSA z dnia 7 lipca 1988 r., IV SA 451/88, „Gospodarka-Administracja Państwowa" 1988, nr 22, s. 43.

7 IV SA 2079/97, LEX nr 48737.

8 VI SA/Wa 2598/17, Legalis nr 1866236. Zob. także: wyrok WSA w Warszawie z dnia 14 listopada 2018 r., VI SA/Wa 1291/18, Legalis nr 1870015. 
stancji w dniu 27 czerwca 2017 r., a więc już w momencie obowiązywania nowych przepisów u.p.f., wprowadzających odmienne kryteria podmiotowe do uzyskania zezwolenia, uznać należało, iż Skarżąca jako spółka kapitałowa nie spełniała już wymagań koniecznych do uzyskania zezwolenia na prowadzenie apteki ogólnodostępnej. W konsekwencji, w myśl art. 101 pkt 1 u.p.f., ww. organ był zobligowany do wydania decyzji odmawiającej udzielenia żądanego zezwolenia".

Przedstawiona wykładnia przepisów art. 94 ust. 4 u.p.f. jest także zbieżna z orzecznictwem sądów administracyjnych w zakresie interpretacji przepisów antykoncentracyjnych (art. 99 ust. 3 i 3 a u.p.f.) co do zakresu ich obowiązywania. Innymi słowy, zgodnie z tą linią orzeczniczą przepisy te nie tylko obowiązują podczas wydawania zezwoleń, lecz także stosuje się je do zezwoleń już wydanych'

Przedmiotem postępowania prowadzonego przez Wojewódzki Sąd Administracyjny w Warszawie nie była ocena wydanego zezwolenia pod rządami poprzednio obowiązujących przepisów, lecz kwestia wydania zezwolenia w odmiennym stanie faktycznym. Gdyby nie doszło do zmiany stanu faktycznego, zainteresowany podmiot w ogóle nie występowałby o zmianę pozwolenia. Postępowanie administracyjne w sprawie zmiany zezwolenia na prowadzenie apteki ogólnodostępnej jest postępowaniem, które $\mathrm{w}$ sensie prawnym jest odrębnym od postępowania administracyjnego w sprawie wydanego już zezwolenia na prowadzenie apteki ogólnodostępnej, które było prowadzone pod rządami poprzednio obowiązujących przepisów i zostało zakończone wydaniem decyzji o zezwoleniu. Przedmiotem obu tych postępowań administracyjnych są odrębne sprawy. Chodzi tutaj o sprawę administracyjną w znaczeniu materialnoprawnym. W praktyce chodzi o udzielenie odpowiedzi na pytania, czy w danym stanie faktycznym organ administracji jest upoważniony do zastosowania konkretnej normy prawnej wobec ściśle określonego podmiotu oraz jaka powinna być treść tego aktu stosowania prawa ${ }^{10}$.

W przypadku pierwszej sprawy (o wydanie zezwolenia pod rządami poprzednio obowiązujących przepisów) była to sprawa o wydanie zezwolenia, oceniana na

9 Zob. wyrok WSA w Warszawie z dnia 23 lipca 2015 r., VI SA/Wa 399/15, Legalis nr 1351604; wyrok WSA w Warszawie z dnia 24 maja 2017 r., VI SA/Wa 2581/1, www.orzeczenia-nsa.pl; wyrok WSA w Warszawie z dnia 26 kwietnia 2017 r., VI SA/Wa 2906/15, Legalis nr 1630750; wyrok WSA w Warszawie z dnia 28 grudnia 2017 r., VI SA/Wa 2690/15, Legalis nr 1731226; wyrok WSA w Warszawie z dnia 5 czerwca 2017 r., VI SA/Wa 425/16, Legalis nr 1725416; wyrok WSA w Warszawie z dnia 6 maja 2017 r., VI SA/Wa 2907/15, Legalis nr 1648552; wyrok WSA w Warszawie z dnia 17 maja 2017 r., VI SA/Wa 173/17, Legalis nr 1630961; wyrok WSA w Warszawie z dnia 28 października 2008 r., VII SA/Wa 1415/08, Legalis nr 172318; wyrok WSA w Warszawie z dnia 13 września 2007 r., VII SA/Wa 1039/07, Legalis nr 268931.

10 Zob. W. Dawidowicz, Zarys procesu administracyjnego, Warszawa 1989, s. 7-8; J. Zimmermann, Administracyjny tok instancji, Kraków 1986, s. 13; T. Woś, Pojęcie „sprawy” w przepisach kodeksu postępowania administracyjnego, „Acta Universitatis Wratislaviensis. Prawo” 1990, nr 1022, s. 334; K. Jandy-Jendrośka, J. Jendrośka, System jurysdykcyjnego postępowania administracyjnego, [w:] System Prawa Administracyjnego, red. T. Rabska, J. Łętowski, t. 3, Wrocław 1978, s. 195-196. 
podstawie obowiązujących wtedy przepisów ustawy Prawo farmaceutyczne, która została zakończona wydaniem decyzji o zezwoleniu. Złożenie wniosku o zmianę zezwolenia oznacza rozpoczęcie nowej sprawy, która dotyczy odmiennego stanu faktycznego. W postępowaniu o zmianę zezwolenia na prowadzenie apteki ogólnodostępnej przedmiotem tego postępowania jest kwestia, czy w danym stanie faktycznym określonemu przedsiębiorcy można udzielić zezwolenia. Prawna ocena tej kwestii jest ściśle związana z zastosowanymi przepisami. To, które przepisy należy zastosować, wyjaśnia przepis intertemporalny art. 2 ust. 1 ustawy nowelizującej. W przypadku postępowań o wydanie lub zmianę zezwolenia na prowadzenie apteki, które zostały wszczęte po dniu wejścia w życie ustawy nowelizującej, stosuje się przepisy nowe, $\mathrm{tj}$. ustawy Prawo farmaceutyczne w brzmieniu ustalonym ustawą nowelizującą.

Przedstawiona interpretacja jest również zgodna z art. 2 Konstytucji Rzeczypospolitej Polskiej z dnia 2 kwietnia 1997 r. ${ }^{11}$, z którego wywodzi się zasadę zaufania obywateli do państwa i stanowionego prawa oraz zasadę ochrony praw nabytych. Wprost o tym stanowi art. 2 ust. 1 ustawy z dnia 7 kwietnia 2017 r., który mówi, że do postępowań wszczętych i niezakończonych przed dniem wejścia w życie ustawy dotyczących wniosków o wydanie zezwolenia na prowadzenie apteki stosuje się przepisy dotychczasowe. Zauważyć należy także, że zarówno w doktrynie, jak i w orzecznictwie Trybunału Konstytucyjnego przyjmuje się, iż ochrona praw nabytych nie ma charakteru absolutnego i dopuszczalne jest ich ograniczenie ${ }^{12}$.

Wojewódzki Sąd Administracyjny w Warszawie wyjaśnił również, że z treści art. 2 ustawy nowelizującej wynika, iż ustawodawca dokonał podziału wydawanych zezwoleń na prowadzenie aptek ogólnodostępnych na zezwolenia funkcjonujące w obrocie na ,starych” oraz na „nowych” zasadach. Według Wojewódzkiego Sądu Administracyjnego wynika to $\mathrm{z}$ faktu, że ustawodawca nie określił żadnego terminu dostosowania funkcjonujących wcześniej zezwoleń do nowych zasad, co oznacza, że nie ustają skutki prawne działania „starego” prawa. Tym samym, według Wojewódzkiego Sądu Administracyjnego, w bieżącym obrocie pozostają - na równych prawach, lecz na odmiennych zasadach - dwa rodzaje zezwoleń na prowadzenie aptek, w zależności od terminu wystąpienia z wnioskiem o ich wydanie.

Wyrażone stanowisko Wojewódzkiego Sądu Administracyjnego wymaga jednak uzupełnienia. Zgodnie z art. 2 ust. 2 ustawy nowelizującej ,,[z]ezwolenia na prowadzenie aptek ogólnodostępnych wydane przed dniem wejścia w życie ustawy zachowują ważność". Ustawodawca nie wprowadził więc nakazu dostosowania się posiadaczy uprzednio wydanych zezwoleń do wymagań przewidzianych ustawą no-

${ }^{11}$ Dz.U. nr 78, poz. 483 ze zm.

12 Zob. M. Safjan, L. Bosek, Konstytucja RP, t. 1: Komentarz do art. 1-86, Legalis 2019, tezy 33-34 do art. 2 oraz przywołane tam orzecznictwo Trybunału Konstytucyjnego, w szczególności wyrok TK z dnia 7 maja 2014 r., K 43/12, OTK-A 2014, nr 5, poz. 50. 
welizującą, ale poczynił ważne zastrzeżenie, że nie dotyczy to postępowań wszczętych po wejściu w życie ustawy nowelizującej, do których mają zastosowanie nowe przepisy. Zgodnie bowiem z art. 2 ust. 1 ustawy nowelizującej do postępowań wszczętych i niezakończonych przed dniem wejścia w życie ustawy nowelizującej dotyczących wniosków o wydanie zezwolenia na prowadzenie apteki stosuje się przepisy dotychczasowe, co oznacza a contrario, że do postępowań wszczętych po dniu wejścia w życie ustawy nowelizującej dotyczących wniosków o wydanie lub zmianę zezwolenia na prowadzenie apteki stosuje się przepisy nowe. Zatem w przypadku zezwolenia, które zostało wydane przed wejściem w życie ustawy nowelizującej, czyli według terminologii Wojewódzkiego Sądu Administracyjnego wydanego na starych zasadach, ale po dniu wejście w życie ustawy nowelizującej, podlegającego zmianie na wniosek jego posiadacza, to do jego zmiany nie będą miały zastosowania stare przepisy, ale nowe, tj. $\mathrm{z}$ ustawy nowelizującej. Innymi słowy, zezwolenie wydane na ,starych zasadach” nie będzie podlegać szczególnej ochronie tylko z tego powodu, że wydane zostało na starych zasadach, w przypadku dokonywania jego zmiany, gdy obowiązują już nowe przepisy. Przyjęcie innej interpretacji, tj. że nie można dokonywać zmiany wydanych wcześniej zezwoleń po wejściu w życie ustawy nowelizującej, niezależnie od wymagań ustawy Prawo farmaceutyczne, prowadziłoby w praktyce do obejścia jej postanowień.

W dalszej części uzasadnienia Wojewódzki Sąd Administracyjny wyjaśnił, że wobec braku uregulowania tej kwestii przez ustawodawcę wykładnia, na jakich zasadach ma dokonywać się taka zmiana, musi mieć z istoty rzeczy złożony charakter, wymaga bowiem dokonania kompleksowej wykładni przepisów, a nie jedynie dopuszczenia podstawowego jej rodzaju, jaką stanowi wykładnia gramatyczna. Należy mieć na uwadze zwłaszcza fakt, że w tym przypadku nie można opierać się wyłącznie na treści nowych przepisów Prawa farmaceutycznego, w szczególności na brzmieniu art. 99 ust. 4, bez należytej oceny hipotezy i dyspozycji cytowanych wyżej regulacji intertemporalnych, określających de facto zakres jego stosowania. Wymaga to zatem zastosowania wykładni systemowej, ale także celowościowej, a nawet historycznej, jeżeli jest to konieczne dla wyjaśnienia intencji (zamiaru) ustawodawcy.

Stosując wskazania Wojewódzkiego Sądu Administracyjnego co do potrzeby stosowania również wykładni celowościowej czy historycznej, należy zauważyć, że postanowienia art. 99 ust. 4 u.p.f. zostały wprowadzone ustawą z dnia 7 kwietnia 2017 r. o zmianie ustawy - Prawo farmaceutyczne ${ }^{13}$ i obowiązują od dnia 25 czerwca 2017 r. Przyjęcie interpretacji, że postanowienia art. 99 ust. 4 u.p.f. stosowane są tylko przy wydaniu zezwolenia, prowadziłoby do takiej sytuacji, że zezwolenia wydane od 2017 r. nie podlegałyby już żadnej kontroli, skoro po ich wydaniu nie można by było stosować np. art. 37ap ust. 1 pkt 2 u.p.f., przewidującego cofnięcie zezwolenia, gdy podmiot przestał spełniać warunki wymagane do wykonywania

\footnotetext{
${ }^{13}$ Dz.U. 2017, poz. 1015.
} 
działalności gospodarczej określonej w zezwoleniu. Innymi słowy, kwestię uzyskania lub zmiany zezwolenia $\mathrm{w}$ oparciu o nowe przepisy, w tym zgodnie $\mathrm{z}$ ochroną praw nabytych (tutaj zezwolenia w kształcie przed wejściem w życie nowych przepisów), należy odróżnić od kwestii przestrzegania warunków określonych przepisami prawa, wymaganych do wykonywania działalności gospodarczej określonej w zezwoleniu. Otrzymanie zezwolenia ,na starych zasadach” i posiadanie go po wejściu w życie nowych przepisów nie oznacza, że podmiot ten nie musi spełniać warunków do wykonywania działalności określonej w zezwoleniu (takimi przepisami są w szczególności przepisy określające warunki, o których mowa w art. 99 ust. 4 u.p.f.). W doktrynie panuje pogląd, że organ zezwalający kontroluje spełnianie przez przedsiębiorcę określonych ustawowo wymogów prowadzenia działalności gospodarczej objętej zezwoleniem, zarówno przed podjęciem działalności gospodarczej, jak i w trakcie jej prowadzenia ${ }^{14}$. W przeciwnym razie doszlibyśmy do niemożliwego do zaakceptowania wniosku, że podmiot, który uzyskał wcześniej zezwolenie, nie będzie już musiał nigdy w przyszłości przestrzegać jakichkolwiek przepisów dotyczących warunków prowadzenia działalności określonej w zezwoleniu, ponieważ te zmiany przepisów nastąpiły po dacie wydania zezwolenia. Nastąpiłoby zanegowanie możliwości działalności prawotwórczej i regulacyjnej na rynku w stosunku do tych podmiotów, skoro kolejne przepisy nie miałyby do nich zastosowania. Podkreśla się więc, że przepisy art. 99 ust. 4 u.p.f. są sformułowane w ten sposób, iż dotyczą oceny spełniania kryteriów w nich wskazanych na chwilę udzielania zezwolenia, ale ze względu na cel ich wprowadzenia, konieczne jest ich przestrzeganie przez cały okres prowadzenia aptek ${ }^{15}$.

Wojewódzki Sąd Administracyjny dopuścił także dowód z pisma Ministra Zdrowia z dnia [...] kwietnia 2019 r., zawierającego odpowiedź na zapytanie o zakres zastosowania nowych przepisów Prawa farmaceutycznego, w odniesieniu do dotychczasowych zezwoleń na prowadzenie aptek ogólnodostępnych. Jak wyjaśnił Wojewódzki Sąd Administracyjny: „Dokonana przez Ministra Zdrowia wykładnia przepisów ma niewątpliwie charakter autentyczny, gdyż Minister Zdrowia jest organem odpowiedzialnym za obszar ochrony zdrowia i jednocześnie organem nadrzędnym w stosunku do Głównego Inspektora Farmaceutycznego. Znaczenie ma także fakt, że przedmiotowa nowelizacja przepisów Prawa farmaceutycznego dokonana została z udziałem konstytucyjnego organu administracji, zaś z uzasadnienia projektu

14 Zob. L. Ogiegło, Prawo farmaceutyczne. Komentarz, Warszawa 2018, Legalis, teza 8 do art. 37ap. Zob. także: C. Kosikowski, Prawo działalności gospodarczej. Komentarz, Warszawa 2002, s. 86; M. Krekora, M. Świerczyński, E. Traple, Prawo farmaceutyczne. Zagadnienia regulacyjne i cywilnoprawne, Warszawa 2008, s. 252.

15 Zob. szerzej: M. Szydło, Opinia prawna o projekcie ustawy o zmianie ustawy - Prawo farmaceutyczne, Druk Sejmowy nr 1126 z 9 stycznia 2017 r.; P. Kościelny, Opinia prawna dotyczaca poselskiego projektu ustawy o zmianie ustawy - Prawo farmaceutyczne, Druk Sejmowy nr 1126 z 23 marca 2017 r. 
ustawy nowelizującej wynika bezpośrednio jej cel”. Według Wojewódzkiego Sądu Administracyjnego z treści cytowanego pisma Ministra Zdrowia i argumentacji w nim zawartej wynika, że nowe regulacje prawne, w szczególności wymagania określone w art. 99 ust. 4 u.p.f., de nomine nie mają zastosowania do zezwoleń na prowadzenie aptek ogólnodostępnych, wydanych na dotychczasowych zasadach.

W ocenie Wojewódzkiego Sądu Administracyjnego „powyższą wykładnię przepisów należy uznać za prawidłową, gdyż znajduje oparcie w szczególności w treści omawianych wyżej przepisów intertemporalnych, których interpretacja ma decydujące znaczenie dla rozstrzygnięcia meritum rozpoznawanej sprawy, nie zaś wykładnia gramatyczna przepisów nowych. Brak jednoznacznie określonego trybu dokonywania zmiany zezwoleń dotychczas funkcjonujących, odmiennie niż to ma miejsce w przypadku zezwoleń nowych, świadczy jednoznacznie o ich pozostawieniu poza zakresem dokonanej zmiany przepisów Prawa farmaceutycznego, które de facto dotyczą zezwoleń nowych. Odmienna interpretacja pozostawałaby w sprzeczności z ratio legis przepisów intertemporalnych uznających »stare« zezwolenia za równoprawne w obrocie gospodarczym. W praktyce prowadziłoby to bowiem do sytuacji, w której każda zmiana dotychczasowych zezwoleń musiałaby dokonywać się na nowych, a nie na starych zasadach, co powodowałoby automatycznie objęcie nowym reżimem prawnym. Taka wykładnia wypaczałaby w istocie sens ww. przepisów intertemporalnych i jednocześnie byłaby skrajnie niekorzystna dla części przedsiębiorców, godząc $w$ prawa nabyte do korzystania $\mathrm{z}$ dotychczasowych zezwoleń, w tym dokonywania ich zmiany na dotychczasowych zasadach".

Wojewódzki Sąd Administracyjny w Warszawie powołuje się na stanowisko Ministra Zdrowia z kwietnia 2019 r. Zauważyć jednak należy, że dotychczas Ministerstwo Zdrowia konsekwentnie prezentowało pogląd, iż powinny być uwzględniane przepisy ustawy Prawo farmaceutyczne nie tylko w trakcie wydawania zezwolenia, lecz także po jego wydaniu w celu zweryfikowania, czy podmiot spełnia wymagania do wykonywania działalności gospodarczej. Tytułem przykładu można wskazać: odpowiedź podsekretarza stanu w Ministerstwie Zdrowia Rafała Niżnikowskiego na interpelację nr 7885/2004 w sprawie antykoncentracyjnych przepisów Prawa farmaceutycznego w kontekście dokonywanych i planowanych zakupów Polskiej Grupy Farmaceutycznej ${ }^{16}$; odpowiedź podsekretarza stanu w Ministerstwie Zdrowia Krzysztofa Łandy na interpelację poselską nr 117 w sprawie wywozu leków za granicę oraz udziału podmiotów w rynku farmaceutycznym (11 stycznia 2016 r.); odpowiedź podsekretarza stanu w Ministerstwie Zdrowia Krzysztofa Łandy na interpelację poselską nr 2718 w sprawie nowelizacji przepisów dotyczących udziału podmiotów w rynku farmaceutycznym ${ }^{17}$; odpowiedź

${ }^{16}$ http://orka2.sejm.gov.pl/IZ4.nsf/main/600ABF81 [dostęp: 10.09.2020].

${ }^{17}$ Odpowiedź na interpelację $\mathrm{nr} 2718 \mathrm{w}$ sprawie nowelizacji przepisów dotyczących udziału podmiotów w rynku farmaceutycznym. Odpowiadający: podsekretarz stanu w Ministerstwie 
podsekretarza stanu w Ministerstwie Zdrowia Marcina Czecha na interpelację poselską nr 19704 w sprawie interpretacji przepisów ustawy Prawo farmaceutyczne

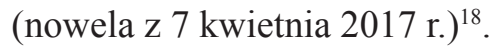

Zważając na powyższe, krytycznie należy ocenić glosowany wyrok oraz argumentację Wojewódzkiego Sądu Administracyjnego w Warszawie zawartą w uzasadnieniu.

\section{BIBLIOGRAFIA}

\section{Literatura}

Błaś A., Boć J., Przepisy przejściowe w prawie administracyjnym, [w:] Prawo administracyjne, red. J. Boć, Wrocław 2005.

Dawidowicz W., Zarys procesu administracyjnego, Warszawa 1989.

Jandy-Jendrośka J., Jendrośka K., System jurysdykcyjnego postępowania administracyjnego, [w:] System Prawa Administracyjnego, red. T. Rabska, J. Łętowski, t. 3, Wrocław 1978.

Kamiński M., Prawo administracyjne intertemporalne, Warszawa 2011.

Kiełkowski T., Sprawa administracyjna, Kraków 2004.

Kosikowski C., Prawo działalności gospodarczej. Komentarz, Warszawa 2002.

Kościelny P., Opinia prawna dotyczaca poselskiego projektu ustawy o zmianie ustawy - Prawo farmaceutyczne, Druk Sejmowy nr 1126 z 23 marca 2017 r.

Krekora M., Świerczyński M., Traple E., Prawo farmaceutyczne. Zagadnienia regulacyjne i cywilnoprawne, Warszawa 2008.

Mikołajewicz J., Prawo intertemporalne. Zagadnienia teoretycznoprawne, Poznań 2000.

Odpowiedź na interpelację nr 19704 w sprawie interpretacji przepisów ustawy Prawo farmaceutyczne (apteka dla aptekarzy). Odpowiadający: podsekretarz stanu w Ministerstwie Zdrowia Marcin Czech, Warszawa, 11.05.2018, www.sejm.gov.pl/sejm8.nsf/InterpelacjaTresc. xsp?key=35C0F540\&view=null [dostęp: 22.08.2020].

Odpowiedź na interpelację nr 2718 w sprawie nowelizacji przepisów dotyczących udziału podmiotów w rynku farmaceutycznym. Odpowiadający: podsekretarz stanu w Ministerstwie Zdrowia Krzysztof Łanda, Warszawa, 12.05.2016, www.sejm.gov.pl/sejm8.nsf/InterpelacjaTresc. xsp?key=39D848F7 [dostęp: 10.09.2020].

Odpowiedź podsekretarza stanu w Ministerstwie Zdrowia na interpelację nr 7885 w sprawie antykoncentracyjnych przepisów Prawa farmaceutycznego w kontekście dokonywanych i planowanych

Zdrowia Krzysztof Łanda, Warszawa, 12.05.2016, www.sejm.gov.pl/sejm8.nsf/InterpelacjaTresc. xsp?key=39D848F7 [dostęp: 10.09.2020]. Zob. także: Pismo z dnia 21 września 2016 r. od Parlamentarnego Zespołu ds. regulacji rynku farmaceutycznego do Ministra Zdrowia Konstantego Radziwiłła, http://orka.sejm.gov.pl/opinie8.nsf/nazwa/441_20160922_1/\$file/441_20160922_1.pdf [dostęp: 12.09.2020].

${ }_{18}$ Odpowiedź na interpelację nr 19704 w sprawie interpretacji przepisów ustawy Prawo farmaceutyczne (apteka dla aptekarzy). Odpowiadający: podsekretarz stanu w Ministerstwie Zdrowia Marcin Czech, Warszawa, 11.05.2018, www.sejm.gov.pl/sejm8.nsf/InterpelacjaTresc. xsp?key=35C0F540\&view=null [dostęp: 22.08.2020]. 
zakupów Polskiej Grupy Farmaceutycznej, http://orka2.sejm.gov.p1/IZ4.nsf/main/600ABF81 [dostęp: 10.09.2020].

Ogiegło L., Prawo farmaceutyczne. Komentarz, Legalis 2018.

Pismo z dnia 21 września 2016 r. od Parlamentarnego Zespołu ds. regulacji rynku farmaceutycznego do Ministra Zdrowia Konstantego Radziwiłła, http://orka.sejm.gov.pl/opinie8.nsf/nazwa/441_20160922_1/\$file/441_20160922_1.pdf [dostęp: 12.09.2020].

Safjan M., Bosek L., Konstytucja RP, t. 1: Komentarz do art. 1-86, Legalis 2019.

Szydło M., Opinia prawna o projekcie ustawy o zmianie ustawy - Prawo farmacentyczne, Druk Sejmowy nr 1126 z 9 stycznia 2017 r.

Woś T., Pojęcie „, sprawy” w przepisach kodeksu postepowania administracyjnego, „Acta Universitatis Wratislaviensis. Prawo" 1990, nr 1022.

Zimmermann J., Administracyjny tok instancji, Kraków 1986.

Zimmermann J., Prawo administracyjne, Warszawa 2014.

Zimmermann J., Problem „, beneficium novorum” w postępowaniu administracyjnym, „Państwo i Prawo" 1987, z. 5.

\section{Akty prawne}

Konstytucja Rzeczypospolitej Polskiej z dnia 2 kwietnia 1997 r. (Dz.U. nr 78, poz. 483 ze zm.). Ustawa z dnia 7 kwietnia 2017 r. o zmianie ustawy - Prawo farmaceutyczne (Dz.U. 2017, poz. 1015).

\section{Orzecznictwo}

Uchwała NSA z dnia 19 października 2015 r., II OPS 1/15, www.orzeczenia-nsa.pl.

Wyrok NSA z dnia 7 lipca 1988 r., IV SA 451/88, „Gospodarka - Administracja Państwowa” 1988, nr 22.

Wyrok NSA z dnia 21 grudnia 1999 r., IV SA 2079/97, LEX nr 48737.

Wyrok NSA z dnia 1 sierpnia 2013 r., I FSK 1245/12, Legalis nr 737538.

Wyrok NSA z dnia 6 sierpnia 2013 r., I FSK 1274/12, Legalis nr 737870.

Wyrok NSA z dnia 22 maja 2015 r., I OSK 2454/13, www.orzeczenia-nsa.pl.

Wyrok SN z dnia 7 maja 2002 r., III RN 59/01, OSNAPiUS 2003, nr 3, poz. 56.

Wyrok TK z dnia 7 maja 2014 r., K 43/12, OTK-A 2014, nr 5, poz. 50.

Wyrok WSA w Warszawie z dnia 13 września 2007 r., VII SA/Wa 1039/07, Legalis nr 268931.

Wyrok WSA w Warszawie z dnia 28 października 2008 r., VII SA/Wa 1415/08, Legalis nr 172318.

Wyrok WSA w Warszawie z dnia 23 lipca 2015 r., VI SA/Wa 399/15, Legalis nr 1351604.

Wyrok WSA w Warszawie z dnia 26 kwietnia 2017 r., VI SA/Wa 2906/15, Legalis nr 1630750.

Wyrok WSA w Warszawie z dnia 6 maja 2017 r., VI SA/Wa 2907/15, Legalis nr 1648552.

Wyrok WSA w Warszawie z dnia 17 maja 2017 r., VI SA/Wa 173/17, Legalis nr 1630961.

Wyrok WSA w Warszawie z dnia 24 maja 2017 r., VI SA/Wa 2581/1, www.orzeczenia-nsa.pl.

Wyrok WSA w Warszawie z dnia 5 czerwca 2017 r., VI SA/Wa 425/16, Legalis nr 1725416.

Wyrok WSA w Warszawie z dnia 27 lipca 2017 r., II SA/Wa 305/17, Legalis nr 1681565.

Wyrok WSA w Warszawie z dnia 28 grudnia 2017 r., VI SA/Wa 2690/15, Legalis nr 1731226.

Wyrok WSA w Warszawie z dnia 23 sierpnia 2018 r., VI SA/Wa 2598/17, Legalis nr 1866236.

Wyrok WSA w Krakowie z dnia 12 września 2018 r., II SA/Kr 598/18, Legalis nr 1825871.

Wyrok WSA w Warszawie z dnia 14 listopada 2018 r., VI SA/Wa 1291/18, Legalis nr 1870015.

Wyrok WSA w Warszawie z dnia 25 czerwca 2019 r., VI SA/Wa 904/19, Legalis nr 2215467. 
Pobrane z czasopisma Studia Iuridica Lublinensia http://studiaiuridica.umes.pl

Data: 26/04/2023 05:01:27

\section{SUMMARY}

The provisions of Article 99 (4) of the Pharmaceutical Law Act stipulate the requirements for obtaining a permit for operating a generally accessible pharmacy by a given entity. The entity operating the pharmacy obtained permission before the amendment of this provision by the amendment to the Pharmaceutical Law, but applied for its change after the entry into force of this amendment. Both the Voivodeship Pharmaceutical Inspector and the Main Pharmaceutical Inspector concluded that the entity applying for a change of authorization to operate a pharmacy, which it obtained before the entry into force of the Amendment Act, must meet the requirements imposed by the currently applicable provisions of the Pharmaceutical Law. The Voivodeship Administrative Court in Warsaw annulled the decisions of both instances appealed by the entity requesting a change of authorization. The gloss to the Court's judgement is critical, in particular as regards the Court's interpretation of the inter-temporal provisions contained in the Amending Act.

Keywords: running a pharmacy; permission to operate a pharmacy; change of authorization to operate a pharmacy; refusal to change authorization 